\title{
The diagnosis and management of food allergies. Position paper of the Food Allergy Section the Polish Society of Allergology
}

\author{
Zbigniew Bartuzi ${ }^{1}$, Maciej Kaczmarski ${ }^{2}$, Mieczysława Czerwionka-Szaflarska ${ }^{3}$, Teresa Małaczyńska ${ }^{4}$, Aneta Krogulska ${ }^{3}$ \\ 1Department of Allergology, Clinical Immunology and Internal Diseases, Ludwik Rydygier Collegium Medicum in Bydgoszcz, \\ Nicolaus Copernicus University in Torun, Poland \\ ${ }^{2}$ Medical University of Bialystok, professor emeritus, Bialystok, Poland \\ ${ }^{3}$ Department of Pediatrics, Allergology and Gastroenterology, Ludwik Rydygier Collegium Medicum in Bydgoszcz, Nicolaus Copernicus \\ University in Torun, Poland \\ ${ }^{4}$ Department of Pediatrics, Allergology and Immunology, Children's Hospital “Polanki”, Gdansk, Poland
}

Adv Dermatol Allergol 2017; XXXIV (5): 391-404 DOI: https://doi.org/10.5114/ada.2017.71104

\begin{abstract}
The paper concerns the current position of the Polish Society of Allergology Food Allergy Section on the diagnosis and management of food allergies. The aim of this position is to provide evidence-based recommendations on the diagnosis and management of patients with allergic hypersensitivity to foods. This position statement includes a systematic review of studies in three areas, namely, the epidemiology, diagnosis and management of food allergies. While taking into account the specific Polish setting, in this publication we also used the current European Academy of Allergy and Clinical Immunology (EAACI) position paper and other current position statements, including those of the United States National Institute of Allergy and Infectious Diseases (NIAID).
\end{abstract}

Key words: food allergy, diagnosis of food allergy, management of food allergy.

\section{Introduction}

Food allergy (FA) is defined as an adverse reaction developing after consumption of food, whose signs and symptoms are caused by immunological mechanisms. These reactions include processes mediated by immunoglobulin E (IgE) and those independent of IgE. Food allergy may contribute to increased mortality and cause life-threatening anaphylactic reactions. The aim of this position statement by the Polish Society of Allergology Food Allergy Section is to provide evidence-based recommendations on the diagnosis and management of patients with allergic hypersensitivity to foods. This position statement includes a systematic review of studies in three areas, namely, the epidemiology, diagnosis and management of food allergies. Only such studies have been included as are characterised by a high scientific quality and raise no methodological or ethical concerns. While taking into account the specific Polish setting, in this publication we also used the current European Academy of Allergy and Clinical Immunology (EAACI) position paper and other current position statements, including those of the United States National Institute of Allergy and Infectious Diseases (NIAID).

\section{Key definitions and classification}

The term adverse reaction to food denotes an incorrect (abnormal) reaction of the body caused by consumption of a specific food or specific chemical compounds added to that food which evoke repeatable and reproducible clinical manifestations [1-4].

In classifications, two categories of human body responses to food are distinguished: toxic reactions and non-toxic reactions.

A toxic reaction is always associated with the same type of clinical symptoms that occur in all the individuals exposed to consumption of the same food. Reactions of this type typically result from one-off consumption of a food containing excess histamine (fish that has gone off), contaminated with bacteria (staphylococci, salmonellae) or toxins (aflatoxins), or containing pharmacologically active compounds (e.g. tyramine in aged cheeses).

Address for correspondence: Prof. Zbigniew Bartuzi MD, PhD, Department of Allergology, Clinical Immunology and Internal Diseases, Ludwik Rydygier Collegium Medicum, Nicolaus Copernicus University, Bydgoszcz, Poland, e-mail: pta@pta.med.pl, zbartuzi@cm.umk.pl Received: 20.07.2017, accepted: 21.07.2017. 


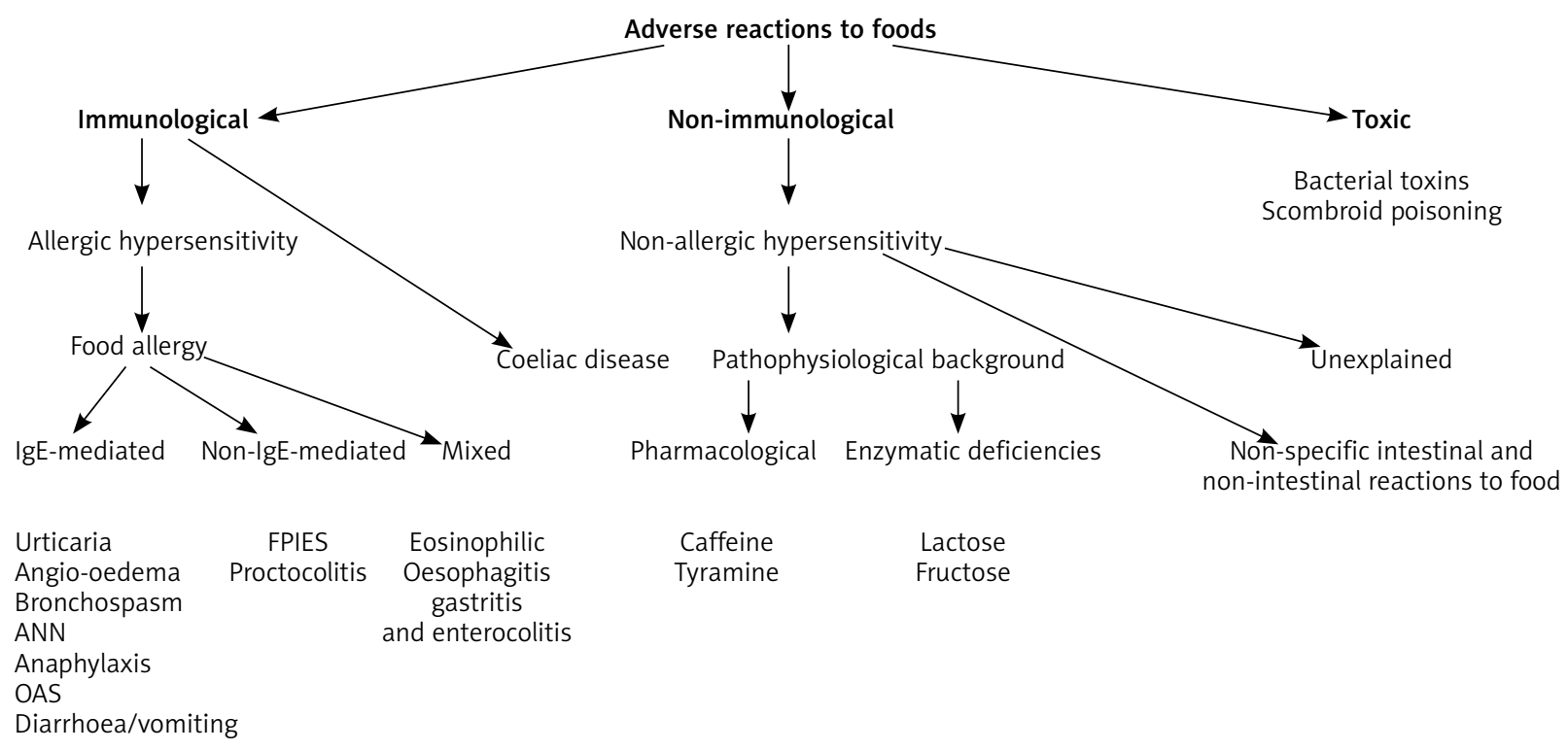

Figure 1. Adverse reactions to foods [6-8]

Non-toxic reactions are attributed to individuals with qualitatively different responses to a food, a specific food ingredient or a chemical substance added to a food. According to the pathogenetic mechanisms of adverse non-toxic reactions to food, patients are divided into two groups: those with FA and those with food intolerance.

Food allergy refers to an adverse reaction of the human body which develops after consumption of food and whose clinical manifestations result from immunological pathogenetic mechanisms.

Food intolerance refers to an adverse reaction of the human body whose clinical manifestations developing after consumption of a specific food result from nonimmunological pathogenetic mechanisms.

Allergic hypersensitivity refers to a reaction of the human body in which the mechanism underlying the clinical manifestations is definitely or likely of an immunological nature (IgE-mediated, non-IgE-mediated, mixed) [5].

Non-allergic hypersensitivity refers to a reaction of the human body in which the involvement of the immunological mechanism as the underlying cause of the clinical manifestations has been ruled out.

A team of experts appointed in 2010 by the National Institute of Allergy and Infectious Diseases (NIAID) developed its own classification of adverse reactions to foods and the principles of diagnosis and management of food allergies [6]. According to American authors, the term adverse food reaction is a broader concept that includes both immunological and non-immunological pathogenetic mechanisms underlying the clinical manifestations caused by food. Among the food-induced reactions occurring with the involvement of immunological pathogenetic mechanisms, the following are distinguished: food allergy and coeliac disease.

According to this classification, food allergy refers to a reaction which develops after consumption of food as a result of one of the following four immunological pathogenetic mechanisms: IgE-mediated, non-IgE-mediated, mixed or cellular.

A food reaction that develops with the involvement of non-immunological mechanisms (metabolic, pharmacological, toxic, idiopathic or unidentified) has been defined food intolerance.

In 2001, members of EAACI and WAO proposed changing the naming of allergic diseases [7]. In the new nomenclature, the concept of hypersensitivity, i.e., the reaction of the organism to a pathogen (e.g. allergen), which does not cause a reaction in healthy individuals, has been introduced. Based on this concept, the term "food allergy" has been attributed to hypersensitivity allergic IgE or allergic hypersensitivity, or non-allergic hypersensitivity [7, 8].

The clarity of these classifications, presented in Figure 1 , makes it more useful in everyday clinical practice.

\section{Epidemiology of food allergies}

The epidemiological studies of the incidence of food allergies have mainly focused on foods of the so-called "Big Eight" group, which comprises food products most commonly consumed by humans in various regions of the world. According to the Food and Agriculture Organisation Report (FAO, 1995) and Codex Alimentarius Commission (1999), these products are a significant source 
of potential food allergens. It is assumed that between 70 and 160 food products and food additives may be causally related to food allergies. It is believed that during infancy and early childhood, the most common cause of sensitisation and the resulting FA are cow milk proteins and chicken egg proteins (approximately $90.0 \%$ of the patients). In adulthood, the principal role in sensitisation and allergic disease is played by hypersensitivity to peanuts and other nuts, fish meat, molluscs/crustaceans and certain fruits and vegetables (approximately 85.0\%) [9-12].

The prevalence of food allergies in the population of children and adolescents and in the adult population has shown an upward trend in the past 20-30 years, as evidenced by the epidemiological studies conducted in multiple countries. The discrepancies in the interpretation of epidemiological study results from different clinical centres stem from the differences in methods and research criteria, which diminishes the comparability of these studies [12-15]. Detailed data on epidemiological studies investigating the incidence of allergic diseases (including food allergies) have been provided by the authors of a report published in 2012 by the World Allergy Organisation (WAO) $[16,17]$.

They established that in 52 out of the 89 countries that are members of this organisation, no epidemiological studies investigating the incidence of food allergies have been conducted. In 23 countries that are members of the WAO, data on FA have been obtained by surveying parents who associated their children's symptoms with consumption of specific foods. Only in 9 countries that are members of the WAO, reliable studies have been conducted during which the diagnosis was confirmed by a positive result of a placebo-controlled food challenge.

According to the WAO report, data on the actual incidence of food allergies diagnosed on the basis of challenge testing are scarce. In the available studies, which focused on the age interval from infancy to 5 years of age, the incidence varies from $1 \%$ in Thailand to $10 \%$ in Australia. Studies conducted in southwest China have shown that the incidence established in infants in three different periods was 7.7\% in 1999, 3.8\% in 2011 and 6.2\% in 2012.

In European countries, the incidence of FA in early childhood has been estimated at 3.6\% in Denmark, $4.0 \%$ in the United Kingdom, and 6.8\% in Norway. The incidence assessed using the same method in schoolchildren was lower in the countries studied, with the lowest value at $0.16 \%$ in Turkey and $2.5 \%$ in the United Kingdom. In German studies, the incidence in the age interval 0 to 17 years has been estimated at $4.3 \%$ with the highest rate being observed in the youngest age group.

A survey study conducted in Poland between 2006 and 2008 was called ECAP (Epidemiology of Allergic Diseases in Poland). The study assessed the incidence of allergic diseases and asthma in Poland in 3 age groups: children aged 6 to 7 years, children aged 13 to 14 years, and adults aged 20 to 44 years. A questionnaire based on the ISAAC and ECRHS II questionnaires was used as a study tool. A total of 20,454 respondents took part in the study. In studies, the age group 0 to 5 years is the most important for the incidence of FA. According to the study results, food allergies reported by the respondents occurred in $13.0 \%$ of the subjects in the age group of 6 to 7 years, $11 \%$ of subjects aged 13 to 14 years, and $5.0 \%$ of the adult subjects [18].

The EAACI has also performed an in-depth analysis of European studies conducted between 2000 and 2012. These studies are summarised in Table 1 . The prevalence of FA in the patients' opinions is six-fold higher than the actual prevalence. According to experts, further population studies with challenge testing are needed to monitor the incidence and predict the further course of food allergies. According to the authors of the Polish Society of Allergology position statement, there is an urgent need for epidemiological studies in Poland, which is among the few European countries lacking any current population data on the incidence of FA $[15,16]$.

Since 2005, an EU-funded, methodologically unified research programme EuroPrevall has been conducted in many European countries. One of the principal goals of this programme was to establish the incidence of IgEmediated FA (especially to cow milk proteins) in the infant population and the population of children and adolescents in 9 European countries. Between 2005 and 2007, the study also included a group of Polish children from the Łódź agglomeration (1260 children aged between $>1$ and 2 years). Final diagnosis was confirmed by double-blind food challenge. It has been established that in the entire European study group of children 2 years old or younger, the incidence of IgE-mediated cow milk protein allergy ranged from $0.00 \%$ (Greece) to $1.3 \%$ (United Kingdom), averaging $0.54 \%$ (95\% confidence interval (CI): 0.41-0.70). In the Polish study group, the incidence of IgE-mediated cow milk protein allergy was established at $0.60 \%(95 \% \mathrm{Cl}: 0.26-1.17)[19,20]$.

\section{Conclusion}

Poland is among the few European countries where up-to-date data on the actual incidence of FA in the paediatric and adult populations are lacking. Epidemiological population studies conducted with the use of a unified research tool (the EuroPrevall questionnaire) and verified by food challenge should be a reference point for the further monitoring and predicting of incidence of food allergies in Poland.

\section{Diagnosis of food allergy}

The diagnosis of FA is one of the more difficult problems that contemporary allergology is facing. There is not a single universal diagnostic method that would allow to establish the diagnosis of FA in each case. The diagnostic difficulties stem, among other things, from the variety 
Table 1. Summary of EAACl epidemiological studies [14]

\begin{tabular}{|c|c|c|c|c|c|c|c|c|}
\hline \multirow[t]{2}{*}{ Parameter } & \multicolumn{2}{|c|}{$\begin{array}{l}\text { Food allergy in the } \\
\text { patient's own opinion }\end{array}$} & \multicolumn{2}{|c|}{$\begin{array}{l}\text { Allergy to a minimum } \\
\text { of one food allergen } \\
\text { (point prevalence) }\end{array}$} & \multicolumn{2}{|c|}{$\begin{array}{l}\text { Clinical manifestations + allergy } \\
\text { to a minimum of one food } \\
\text { allergen (point prevalence) }\end{array}$} & \multirow{2}{*}{$\begin{array}{l}\text { Convincing } \\
\text { history or } \\
\text { positive } \\
\text { challenge } \\
\text { (point } \\
\text { prevalence) }\end{array}$} & \multirow{2}{*}{$\begin{array}{c}\text { Positive open } \\
\text { food challenge } \\
\text { or DBPCFC } \\
\text { (point } \\
\text { prevalence) }\end{array}$} \\
\hline & $\begin{array}{l}\text { Lifetime } \\
\text { prevalence }\end{array}$ & $\begin{array}{c}\text { Point } \\
\text { prevalence }\end{array}$ & $\begin{array}{c}\text { Positive } \\
\text { specific lgE }\end{array}$ & $\begin{array}{l}\text { Positive skin } \\
\text { prick test }\end{array}$ & $\begin{array}{c}\text { Clinical } \\
\text { manifestations } \\
+ \text { positive } \\
\text { specific IgE }\end{array}$ & $\begin{array}{c}\text { Clinical } \\
\text { manifestations } \\
+ \text { positive skin } \\
\text { prick test }\end{array}$ & & \\
\hline Total & $\begin{array}{c}17.3 \\
(17.0-17.6)\end{array}$ & $\begin{array}{c}5.9 \\
(5.7-6.1)\end{array}$ & $\begin{array}{c}10.7 \\
(9.4-10.8)\end{array}$ & $\begin{array}{c}3.0 \\
(2.7-3.3)\end{array}$ & $\begin{array}{c}2.7 \\
(1.7-3.7)\end{array}$ & $\begin{array}{c}1.5 \\
(1.3-1.7)\end{array}$ & $\begin{array}{c}2.6 \\
(2.1-3.1)\end{array}$ & $\begin{array}{c}0.9 \\
(0.8-1.1)\end{array}$ \\
\hline \multicolumn{9}{|l|}{ Age: } \\
\hline $\begin{array}{l}\text { Children } \\
\text { (0-17 years } \\
\text { old) }\end{array}$ & $\begin{array}{c}17.4 \\
(16.9-18.0)\end{array}$ & $\begin{array}{c}6.9 \\
(6.6-7.2)\end{array}$ & $\begin{array}{c}12.2 \\
(11.4-13.1)\end{array}$ & $\begin{array}{c}3.0 \\
(2.7-3.3)\end{array}$ & $\begin{array}{c}3.6 \\
(2.8-4.4)\end{array}$ & $\begin{array}{c}1.5 \\
(1.3-1.7)\end{array}$ & $\begin{array}{c}2.6 \\
(2.1-3.1)\end{array}$ & $\begin{array}{c}1.0 \\
(0.8-1.2)\end{array}$ \\
\hline $\begin{array}{l}\text { Adults } \\
\text { ( }>18 \text { years } \\
\text { old) }\end{array}$ & $\begin{array}{c}17.2 \\
(16.0-17.6)\end{array}$ & $\begin{array}{c}5.1 \\
(4.8-5.3)\end{array}$ & $\begin{array}{c}4.1 \\
(3.2-5.1)\end{array}$ & $-^{\star}$ & $\begin{array}{c}2.2 \\
(0.8-3.7)\end{array}$ & $-^{*}$ & $-^{\star}$ & $\begin{array}{c}0.9 \\
(0.8-1.0)\end{array}$ \\
\hline \multicolumn{9}{|l|}{ Regions`: } \\
\hline $\begin{array}{l}\text { Western } \\
\text { Europe }\end{array}$ & $\begin{array}{c}23.8 \\
(22.9-24.7)\end{array}$ & $\begin{array}{c}3.3 \\
(3.1-3.5)\end{array}$ & $\begin{array}{c}11.7 \\
(9.8-13.6)\end{array}$ & $\begin{array}{c}1.8 \\
(1.5-2.1)\end{array}$ & $\begin{array}{c}2.6 \\
(1.3-3.8)\end{array}$ & $\begin{array}{c}1.4 \\
(1.1-1.7)\end{array}$ & $-^{*}$ & $\begin{array}{c}3.1 \\
(2.6-3.7) \\
\end{array}$ \\
\hline $\begin{array}{l}\text { Eastern } \\
\text { Europe }\end{array}$ & $\begin{array}{c}41.6 \\
(39.5-43.7)\end{array}$ & $\begin{array}{c}3.3 \\
(1.2-5.4)\end{array}$ & $-^{*}$ & $-{ }^{*}$ & $-{ }^{*}$ & $-^{*}$ & $-^{\star}$ & $-^{*}$ \\
\hline $\begin{array}{l}\text { Southern } \\
\text { Europe }^{\#}\end{array}$ & $\begin{array}{c}8.6 \\
(8.2-9.0)\end{array}$ & $\begin{array}{c}3.5 \\
(2.5-4.5)\end{array}$ & $-^{*}$ & $\begin{array}{c}4.2 \\
(2.2-6.3)\end{array}$ & $-{ }^{*}$ & $\begin{array}{c}1.8 \\
(1.3-2.3)\end{array}$ & $-{ }^{*}$ & $\begin{array}{c}0.2 \\
(0.1-0.3)\end{array}$ \\
\hline $\begin{array}{l}\text { Northern } \\
\text { Europe }\end{array}$ & $\begin{array}{c}30.3 \\
(28.7-31.9) \\
\end{array}$ & $\begin{array}{c}14.5 \\
(13.9-15.2)\end{array}$ & $\begin{array}{c}9.8 \\
(9.0-10.5) \\
\end{array}$ & $\begin{array}{c}5.4 \\
(4.6-6.1) \\
\end{array}$ & $\begin{array}{c}3.0 \\
(2.1-3.9) \\
\end{array}$ & $\begin{array}{c}1.6 \\
(0.9-2.3) \\
\end{array}$ & $\begin{array}{c}2.6 \\
(2.1-3.1) \\
\end{array}$ & $\begin{array}{c}1.1 \\
(0.9-1.3)\end{array}$ \\
\hline Europe $e^{\star *}$ & $\begin{array}{c}19.2 \\
(18.6-19.8)\end{array}$ & $\begin{array}{c}5.0 \\
(4.6-5.5)\end{array}$ & $-^{\star}$ & $-^{*}$ & $-^{*}$ & $-^{*}$ & $-^{*}$ & $-{ }^{*}$ \\
\hline
\end{tabular}

Point prevalence is the proportion of a population that has the condition at a specific point in time. *No studies for this group of the primary endpoint. ${ }^{* *}$ For studies which included several European countries and reported estimated data for all the countries and in which it is not possible to calculate the prevalence for each country investigated. ${ }^{\S}$ Regions of Europe as classified by the United Nations (UN). \#Studies from Turkey added. @If both open food challenge and DBPCFC were carried out in a study, the DBPCFC was always taken into account. If no DBPCFC was carried out, then open food challenge was taken into account. The data in the table is given as percentages $(95 \% \mathrm{CI})$. DBPCFC - double-blind placebo-controlled food challenge.

of foods, the variability of their sensitising potencies, the various routes through which food enters the body, the conditions in which foods are stored, the various underlying mechanisms of allergic reactions etc. All this generates an urgent need for further, more precise diagnostic methods and for education on the recommended research tools [21].

All the international guidelines on the diagnosis of FA emphasise that the first diagnostic step is the history based on which skin prick test (SPT) or slgE with the potential allergens are carried out. Diagnostic elimination diets and challenge tests play an extremely important role. Molecular testing is considered to be the third diagnostic step and is pursued when the first and second diagnostic steps are inconclusive [3].

The presence of slgE, just as positive SPT results, do not always indicate a clinically relevant allergy. Therefore, the results of testing must always be interpreted in the context of the patient's history and, in doubtful cases, confirmed by food challenge (evidence $\mathrm{A}-\mathrm{C}$ according to EBM). If historical data indicate allergy to a specific food, negative testing results must also be interpreted with considerable caution as non-IgE-mediated hypersensitivity may be responsible for the clinical manifestations in such cases (evidence C) [22]. Routine determination of clgE is not, however, recommended. Assessment of slgE levels is only useful in patients with severe atopic dermatitis as very high clgE levels may yield false positive results of slgE testing (evidence D). The sensitivity of slgE determination is relatively low, ranging from $10 \%$ to $25 \%$ for clinically relevant reactions, including anaphylaxis. This means that most results may be false positive or false negative. In such situations, food challenge is necessary to confirm the diagnosis. The rate of false positive or negative results will largely depend on the diagnostic method (quantitative, semi-quantitative or qualitative methods of determining slgE) [22]. The lack of congruence between skin tests and the presence of slgE and the poor correlation with the clinical manifestations mean that these tests cannot be used as screening tests in the diagnosis of FA. The COPSAC study has shown a significant discrepancy between SPT results and the presence of sIgE (determined by ImmunoCAP), which increased with the child's age (Figure 2). 
This means that these tests can be used interchangeably, and in doubtful cases, food challenges are necessary to establish the appropriate diet.

Sampson used double-blind, placebo-controlled food challenge (DBPCFC) to assess the clinical relevance of allergy depending on slgE levels. The positive predictive values (PPVs) of slgE for the major food allergens are given in Table 2 [23]. For some allergens, for a specific level of antibodies, PPV may be up to $95 \%$. While it cannot serve as the basis for assessing the severity of FA symptoms, it does, in many patients, allow to resign from the frequently time-consuming DBPCFC (Table 3) [24].

Assessment of slgE levels may also be useful for the assessment of tolerance development in a child previously found allergic to a specific food. A 50-percent decline in slgE levels from baseline is associated with a 50-percent likelihood of developing tolerance, which has been confirmed in food challenges [25].

Molecular diagnosis with the assessment of slgE to allergen components constitutes a significant progress in the diagnosis of allergy. Two methods for determination of slgE are available: a quantitative method (ImmunoCAP) and a semi-quantitative method (ISAC) $[3,4]$. This method is merely the next diagnostic step in patients with confirmed lgE-mediated hypersensitivity and in patients with inconclusive results of SPT or SlgE with food allergens. This method has allowed to discover that cow milk and wheat contain more than 40 allergen components and chicken egg white contains 23 . The knowledge of hypersensitivity to specific allergen components not only allows to select a suitable diet but also to assess the risk of the chronic course of allergy symptoms, the likelihood of developing immunotolerance and the reaction to thermally processed foods. For example, in children with milk allergy, levels of slgE to the thermostable fraction of milk, casein, exceeding $6.6 \mathrm{kU} / \mathrm{l}$ (by ImmunoCAP) almost always indicate the clinical relevance of allergy. Children with high levels of this antibody develop tolerance less frequently and generally do not tolerate thermally pro-

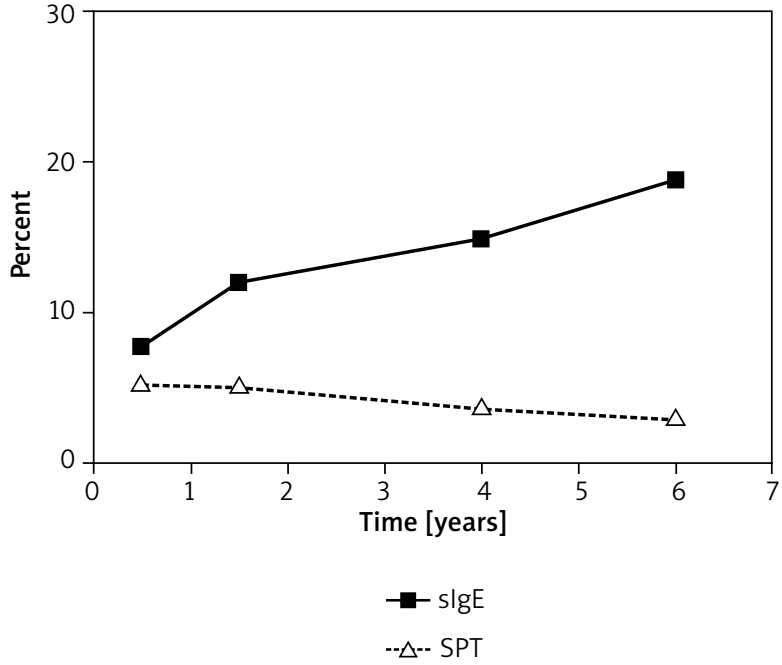

Figure 2. Food allergy: the relationship between SPT results and slgE results that change with age [22]

cessed milk. Similarly, based on the presence of slgE to Ara $h 2$, already at a cut-off value of 0.65 ISU (by ISAC), patients with clinically relevant allergy to peanuts can be differentiated with a very high likelihood (sensitivity 99.1\%, specificity 98.6\%) from patients with asymptomatic allergy, even though slgE levels to the entire peanut allergen are not elevated. Based on this, however, patients at an increased risk of anaphylaxis induced by peanuts cannot be identified [26-29].

In conclusion, molecular testing offers, among other things, the possibility to assess the clinical relevance of allergy to specific food allergens, to expand the diagnostic evaluation in patients with multiple food allergies, to identify foods that cross-react with pollen, to assess the likelihood of developing tolerance to food allergens, and to conduct a detailed diagnostic evaluation of patients with a history of the anaphylactic reaction. In cases of positive results to multiple allergen components, the fol-

Table 2. Tests identifying a food allergen and establishing the diagnosis of IgE-mediated food allergy [23]

\begin{tabular}{lcc}
\hline Test & Can it identify a food allergen? & Can it diagnose food allergy? \\
\hline Skin prick/puncture test & Yes & No \\
\hline Intradermal testing & Yes (but test poses a risk of adverse & No \\
& Noctions) & No \\
\hline Total serum lgE & Yes & No \\
\hline Allergen-specific lgE in the serum & No & No \\
\hline Atopy patch test & Yes & Probably \\
\hline $\begin{array}{l}\text { Combination of skin prick/puncture test, } \\
\text { slgE test, and atopy patch test }\end{array}$ & Yes & Probably \\
\hline Food elimination diet & Yes (but the test poses a risk of adverse & Yes \\
\hline Oral food challenge & reactions) & \\
\hline
\end{tabular}


Table 3. Predictive values of slgE for food allergens (using CAP System) [24]

\begin{tabular}{lcc}
\hline Allergen & slgE $[\mathrm{kU} / \mathrm{l}]$ & PPV (\%) \\
\hline Egg & 7 & 98 \\
\hline Egg < 2 yo & 2 & 95 \\
\hline Milk & 15 & 95 \\
\hline Milk <2 yo & 5 & 95 \\
\hline Peanuts & 14 & 100 \\
\hline Fish & 20 & 100 \\
\hline Tree nuts & 15 & 95 \\
\hline Soya & 30 & 73 \\
\hline Wheat & 26 & 74 \\
\hline
\end{tabular}

lowing questions should be answered: Is this a clinically relevant allergy? Are the results congruent with those of SPT or slgE to the entire allergen? If not, are the results congruent with the patient's clinical manifestations?

Could a cross-reaction between the individual components explain the positive result of SPT or slgE to the entire allergen?

Are slgE to thermolabile components (e.g. prophyllin, CCD) or thermostable components (storage proteins, LTP, Tri a 19) present, which can be responsible for anaphylactic reactions?

It should also be kept in mind that with ISAC, the detection of slgE to a single allergen component only occurs occasionally and if it does, the test needs to be repeated using the CAP System.

Another research tool recommended by international scientific experts is the basophil activation test (BAT). The test uses flow cytometry and, thanks to its high sensitivity and specificity, is among the tests which provide an alternative to the traditional diagnostic methods, particularly in the case of more complex allergies or untypical allergens. Depending on the specific allergen being tested for, the sensitivity and specificity of BAT in the diagnosis of food allergies are estimated at 77-98\% and 75-100\%, respectively. In accordance with EAACI recommendations, there is a need for unification of the procedures and allergen concentrations in BAT and for standardisation and automation of the analysis. The BAT may undoubtedly help to reduce the need for challenge testing [6].

We would like to draw attention to commercial tests available on the Polish market, which are not recommended for the diagnosis of food allergies. Based on our experience, the use of these tests results in enormous confusion [6, 30, 31] (Table 4).

\section{Diagnostic elimination diets}

A diagnostic diet involves elimination of foods suspected to trigger an allergic reaction based on the pa-
Table 4. Test that are not recommended for the diagnosis of food allergy [3]

slgG assessment (According to the EAACI/WAO position paper, the presence of slgG to foods is of no diagnostic relevance in FA, and merely indicates previous exposure to a specific potential food allergen (Stapel, Tomićić))

\begin{tabular}{l}
\hline Chemical hair analysis \\
\hline Iridology \\
\hline BICOM ectodermal test \\
\hline Lymphocyte stimulation test \\
\hline Gastric content analysis \\
\hline
\end{tabular}

tient's history, analysis of the food diary, assessment of slgE and SPT.

Although there are no well-documented studies investigating the diagnostic role of elimination diets in establishing the diagnosis of food allergies, it is an important element of the diagnostic process.

Based on the analysis of the food diary, the causative and temporal relationships can be preliminarily established between specific foods and the patient's clinical manifestations, and it can be determined with a high level of probability whether the patient suffers from IgEmediated or non-IgE-mediated hypersensitivity (level of evidence D) [5].

Assessment of the efficacy of a diagnostic diet is very subjective and as such it is not always helpful establishing the preliminary diagnosis. In addition, the clinical manifestations may worsen even after exposure to the food by inhalation or contact. It seems that the usefulness of a diagnostic elimination diet is higher if non-lgE-mediated reaction is being suspected. If the most likely allergen cannot be identified from the history, then no more than two potential allergens should initially be eliminated from the eight major food allergens: milk, egg white, wheat, nuts, peanuts, crustaceans, seafood, and soya. Of more than 170 potential food allergens, these are responsible for as many as $85-90 \%$ of the reactions [6]. The predominant allergies in children are those to milk, egg proteins, wheat and soya, while allergies to seafood, vegetables and fruits are the prevailing food allergies in adults [32].

An elimination diet can be started at home. The duration of the diet depends on the organ(s) affected by the FA, the severity of symptoms, the duration of symptoms and the patient's age. If IgE-mediated hypersensitivity is suspected, 2 weeks of observation are usually sufficient, while non-lgE-mediated hypersensitivity requires a 4-week observation. In some cases, in patients with severe atopic dermatitis or eosinophilic oesophagitis, this period should be extended to 6 weeks. Extending the duration of an elimination diet without a clear confirmation of FA is not recommended [3, 5, 33]. 
Table 5. Recommendations on the diagnosis of food allergy using elimination diets, according to EAACI [3]

\begin{tabular}{lccc}
\hline EAACI recommendations [5] & Evidence level & Grade & References \\
\hline $\begin{array}{l}\text { Avoidance of foods identified on the basis of food diary analysis. History and test } \\
\text { results: SPT and/or slgE }\end{array}$ & $\mathrm{V}$ & $\mathrm{D}$ & Expert opinion \\
\hline $\begin{array}{l}\text { Each suspected food should be eliminated, and efficacy assessed after 2 to 4 weeks } \\
\text { If there is a considerable improvement after introduction of an elimination diet, the diet } \\
\text { should be continued as a treatment diet until the scheduled follow-up challenge }\end{array}$ & $\mathrm{V}$ & $\mathrm{V}$ & Expert opinion \\
\hline \begin{tabular}{l} 
If no clinical improvement is achieved after using a diet, the diagnosis of FA is unlikely \\
\hline
\end{tabular} & $\mathrm{V}$ & $\mathrm{D}$ & Expert opinion \\
\hline
\end{tabular}

Where a correctly followed elimination diet, monitored with a food diary, fails to improve the clinical manifestations, the diagnosis of FA is unlikely.

In severe FA, an oligoallergenic diet is recommended, and in small children, an elimination diet with AAF should be used.

Each ingredient of the diet should be determined individually, sometimes depending on the results of skin tests or the presence of slgE.

If there is no suspicion of serious allergic reactions in the history, the eliminated foods may be gradually introduced in the diet at home. If, however, the history suggests that the reaction was severe, these foods should be introduced under close medical supervision in the setting of open challenge or double-blind placebo-controlled food challenge, as in these patients, a re-challenge with even minimal amounts can trigger a severe anaphylactic reaction.

If the child is breastfed, the mother is instructed to follow an elimination diet for 2 to 6 weeks. Such diet is usually started from eliminating two major potential allergens, i.e. milk and egg proteins [26, 34-36]. The mother should not eliminate too many foods from her diet, especially fruits and vegetables. If despite that symptoms persist, hypersensitivity to milk and chicken egg proteins can be eliminated with a high degree of likelihood, and the mother should gradually reintroduce these foods in her diet.

In exceptional cases, if severe allergy to cow milk proteins is suspected or if symptoms persist despite following a restrictive milk-free diet, breastfeeding should be discontinued [26, 34, 35]. Beta-lactoglobulin is not present in human milk [37]. Its concentration after drinking approximately $500 \mathrm{ml}$ of cow milk is very low and comparable to the concentration found in high-grade casein hydrolysates, which is why the infant should be fed an elemental diet directly after breastfeeding cessation [36]. Before potential resumption of breastfeeding the mother should resume a milk-free diet at least $72 \mathrm{~h}$ before.

In adults, if no improvement is seen on the oligoallergenic diet and where there is a reasonable suspicion of FA, it is possible to introduce the so-called "tea break", but not for more than 5 days. If no clinical improvement is seen, continuation of the diet is no longer justified and it can be gradually expanded under close medical supervision, by food challenges (usually open challenges, and in doubtful cases, by double-blind placebo-controlled challenge). It is not until the result of a challenge is positive that the specific food is permanently eliminated from the diet. If the result of a challenge is negative, the diagnosis of FA can be ruled out with a high level of probability (Table 5).

\section{Food challenge tests}

Establishing the diagnosis of FA is a complex, stepwise and time-consuming process. It involves taking a detailed personal and family history of allergy, performing a thorough physical examination, interpreting the findings and correct planning of allergic and immunological testing. The method that provides a conclusive indication of a causal relationship between the foods consumed by the patient and the patient's clinical manifestations triggered by an allergic process is the oral food challenge test (OFCT).

\section{Definition}

An oral food challenge test (OFCT) is a biological diagnostic test that involves the administration of increasing amounts (doses) of a food suspected to trigger allergic symptoms in a patient with an abnormal reaction to food.

\section{Aims of food challenge testing}

- To confirm or rule out a causal relationship between the test food and the type of clinical manifestations presented by the patient.

- To assess the reproducibility and repeatability of the clinical manifestations of FA compared to those before the challenge.

- To assess the reproducibility and repeatability of the clinical manifestations of FA compared to those during the previous positive challenge test.

- To draw conclusions on the pathogenetic mechanism of the food-induced allergic reaction based on the time from the intake of the challenge dose of the food to the development of clinical manifestations:

- Immediate reaction (IgE-mediated mechanism).

- Delayed reaction (mixed mechanism, IgE-mediated/ non-lgE-mediated).

- Late reaction (cellular mechanism, T-cell-mediated). 


\section{Indications for food challenge testing}

- To confirm or exclude a cause of FA.

- To assess the development of tolerance to an initially harmful food (after a specific duration of an elimination diet).

- To assess the possibility to expand the diet in a patient with allergy to multiple foods, eliminating several foods.

\section{Types of oral food challenge testing}

Classification with respect to patient's age and testing procedure:

- Open food challenge (performed until 3 years of age) All the parties involved (the child, the parents/caregivers, the doctor, the nurse) know which food (allergen) the patient is exposed to.

- Single-blind challenge - The patient and their caregivers are not informed whether the test sample contains the challenge food or placebo. The composition of the sample is known to the person performing the test (the doctor, the nurse).

- Double-blind placebo-controlled food challenge - Neither the patient/caregivers, the doctor nor the nurse know the challenge food. The challenge food and placebo are prepared by a third party (a dietician).

\section{Selection of the type and dose of the food and the venue of the challenge test}

The type of the challenge test (open, single-blind, double-blind) and the place where it is to be performed should be decided on an individual basis with respect to each patient. The following factors should be taken into consideration during the decision process:

- The possibility of preparing the oral food challenge (including blinded samples) and for patient monitoring during the test.

- The timing of allergic symptoms and the possibility of developing immediate symptoms (anaphylactic shock).

\section{Principles of preparing food challenges Open food challenge}

Testing begins with the intake of a predefined initial dose of the challenge food, followed by the intake of in-

Table 6. Principles of interpretation of challenge results

\begin{tabular}{ccc}
\hline \multicolumn{2}{c}{ Food challenge result } & Interpretation \\
\hline $\begin{array}{c}\text { With allergen } \\
\text { Positive }(+)\end{array}$ & With placebo & $\begin{array}{c}\text { Confirmation } \\
\text { of food allergy }\end{array}$ \\
\hline With allergen & With placebo & Repeat challenge \\
Positive $(+)$ & Positive $(+)$ & \\
\hline With allergen & With placebo & $\begin{array}{c}\text { No confirmation } \\
\text { of food allergy }\end{array}$ \\
Negative $(-)$ & Negative $(-)$ & Repeat challenge \\
With allergen & With placebo & (open) \\
Negative $(-)$ & Positive $(+)$ &
\end{tabular}

creasing portion sizes at predefined time points (usually every 15-30 min) until the portion size (volume) normally consumed by the patient is achieved. In the case of allergy to cow milk proteins, testing begins with the initial dose of $1-5 \mathrm{ml}$ if the risk is low and $0.05-0.1 \mathrm{ml}$ if the risk is high. The initial dose of other foods tested in the challenge test has been established at $0.15-0.3$ g of protein per $\mathrm{kg}$ body weight, to be gradually increased every $15-30$ min [38, 39].

Before the intake of each subsequent dose of the challenge food, the patient's clinical condition is assessed.

\section{Blinded food challenge}

Blinded food challenge involves the mixing of the suspected product with a masking matrix (elemental formula in the case of cow milk) or the placement of the test product (e.g. egg white) in another masking matrix. The test product and placebo are blinded independently. They are usually tested during 2 separate sessions on 2 separate days (active product on one day and placebo on the other). After the diagnostic procedure is complete, the samples are unblended (Table 6).

After completion of the challenge, if the result is negative, an open challenge should be performed where the test product is ingested in its natural form. Observation should be conducted for several days due to the possibility of developing a late allergic reaction.

\section{Safety of challenge testing}

Before a decision is made to perform oral food challenge, the risks of adverse reactions, particularly lgE-mediated systemic reactions and anaphylactic shock, should be assessed.

For this reason all food challenges are performed under supervision of an experienced doctor (in a hospital ward, at a specialist clinic). Equipment and medication for immediate life-saving intervention must be available in the room in case the patient develops an anaphylactic shock (intubation set, oxygen, pre-filled pen with epinephrine, ensuring venous access).

An open challenge can be performed in the outpatient setting, in the office, having verified that the patient is not at a risk of shock reaction (negative testing results for IgE-mediated allergic reactions with the challenge food). Further intake of the challenge food may be continued at home according to the guidelines established by the doctor $[12,40,41]$.

\section{Final comments}

The patient undergoing an oral challenge test should be healthy on the day of testing (in remission of allergic manifestations and with no signs of acute infection).

Infants undergoing challenge testing should not remain fasting for more than $2 \mathrm{~h}$; older children and adults should be in the fasting state. 
Before the scheduled challenge, some medicines should be discontinued as these may interfere with the interpretation of the oral food challenge results (antiallergic medication, antihistamine medication, steroids at least 3 days before the challenge).

Before the challenge and after each intake of the challenge food portion, the patient should be examined (symptom monitoring, BP, respiratory rate).

\section{Education}

Food allergy considerably impacts not only the patient's quality of life but also that of their families. In light of the high prevalence, the upward trend in incidence and the potential consequences of the disease, multiple management guidelines have been developed for FA, each giving consideration to the important role of education [4]. Education should not only be provided to healthcare professionals, the patients and their families, but also nursery, kindergarten and school teachers, food product providers, restaurant staff, bakery staff, and officials, particularly those responsible for inspecting catering facilities.

Education of the parents of children with FA is of principal significance. Small children must be supervised and taught that, while they should share their toys, they should not share their food. Older children and adolescents should be informed that meals prepared outside their homes may contain food allergens, hence learning to read food product labels is an important element of education. It should, for example, be noted that whey or casein are cow milk proteins, which may be the so-called hidden sources of milk. Regulation (EU) No. 1169/2011 of the European Parliament and of the Council of 25 October 2011 entered into force on 13 December 2014. It concerns the new principles of provision of information on the labels of each processed food product. The same definitions, requirements and procedures will apply throughout

Table 7. Cross-reacting foods [32, 33]

\begin{tabular}{lc}
\hline Allergen & Cross-reaction \\
\hline Cow milk & Goat milk (90\%); beef (10\%) \\
\hline Chicken egg & Turkey, duck, goose eggs \\
\hline Soya & Rare cross-reaction with other legumes \\
\hline Peanuts & Other legumes are usually well-tolerated \\
\hline Fish & Significant cross-reaction with other \\
species of fish
\end{tabular}

the European Union, thanks to which the consumer will be provided with reliable information on issues including potential food allergens and food additives present in food products responsible for allergic reactions or symptoms of intolerance (Annex II to the Regulation). These will be underlined on the packaging using a print that clearly stands out of the rest of the ingredients, for example, by means of the font, style or background colour [4].

The principal goal of education is to be able to identify the first symptoms of the anaphylactic reaction after ingestion of a sensitising food and to acquire the skill of administering adrenaline. Delayed administration of adrenaline has been shown to be a serious life threat, with the highest risk of anaphylaxis being observed in patients with IgE-mediated hypersensitivity. These patients should be provided with anaphylaxis bracelets [2].

Each patient with FA should be provided with exhaustive information (also in writing) about the necessity to avoid foods responsible for triggering allergic reactions, about the possibility of developing cross-allergy to other foods (Table 1), pollen (Table 2 ) and about the rapid response to the anaphylactic reaction [5]. When devising a management plan for a patient with FA, it is important to take into account the risk level, the presence of asthma and the impact of dietary restrictions on nutritional status. An important role of the dietician in establishing dietary recommendations should also be emphasised here.

Another important element of education is the provision of information on the possible methods of FA prevention, the principles of determining the composition and duration of elimination diets, and the cofactors that can affect the severity of allergic reactions to foods. It would be justified to establish education centres that would provide ongoing training to paediatricians, GPs, school nurses, dieticians, teachers and nursery school and kindergarten staff. Patient education is the mainstay of effective treatment of food allergies (Tables 7, 8).

\section{Prevention of nutritional disorders}

Introduction of an elimination diet may lead, mainly in children, to nutritional disorders. Children aged 3 years or younger are at the highest risk of nutritional disorders [42]. At this age, the child develops the fastest,

Table 8. Cross-reactions between pollen and fruits and vegetables in patients with OAS [5]

\begin{tabular}{lc}
\hline Birch & $\begin{array}{c}\text { Apple, cherry, apricot, carrot, potato, kiwi fruit, } \\
\text { hazelnuts, celery, pear, soya, peanuts }\end{array}$ \\
\hline Ambrosia & Melon, banana \\
\hline Grasses & Kiwi fruit, tomato, watermelon, potato \\
\hline Sagebrush & Celery, garlic, carrot, parsley \\
\hline Latex & Banana, avocado, hazelnuts, kiwi fruit, fig, \\
apple, cherry
\end{tabular}


hence the requirement for various nutrients is much higher than in adults. Each elimination diet, both in children and in adults, must first of all be safe and provide appropriate quantities of protein, fat, vitamins and minerals. Consultation with a dietician is necessary when compiling a diet. Sufficiently early detection of potential dietary deficiencies always requires development of a plan of follow-up visits during which the weight and height gain should be monitored. This should be done at 1, 2 and 4 months of age in children aged 6 months or younger, every 3 months in children aged 12 months or younger, and every 6 to 12 months in older children. If the weight and height gain is age-appropriate, the follow-up may be done once a year, otherwise at least twice a year [43].

Elimination of basic dietary ingredients from the diet means elimination of essential sources of vitamins and minerals (Table 9), which also affects the development of nutritional disorders. The problem of nutritional disorders in children with FA became the focus of attention only several years ago. Results of a unique study conducted in 2010 in a large group of 9500 children below 24 months of age with FA have revealed nutritional disorders in every fifth child. Growth retardation in every fourth child before 6 months of age was the most striking finding. Weight deficit was not, however, observed until after 12 months of age [44]. Similar conclusions follow from a study published in 2014 [45]. The study assessed weight and height in 9938 children (mean age: 68 months). A total of 439 (4.4\%) of them were diagnosed with FA. Children with food allergies were shorter than healthy children, and children with milk allergy were also lighter. Growth impairment may be irreversible, as suggested by the conclusions from a study in $30 \mathrm{pa}$ tients aged $19.5 \pm 1$ years with IgE-mediated milk allergy, who ate a milk-free diet since infancy. The final height of these patients in adult life was much lower than in the group of 19 healthy individuals (aged $21.3 \pm 3.6$ years) $(p<0.05)[46]$.

The risk of growth impairment is higher if [43]:

- The onset of symptoms occurs in early childhood.

Table 9. Micro- and macroelements in eliminated food allergens

\begin{tabular}{lc}
\hline Allergen & Vitamins, minerals \\
\hline Milk & $\begin{array}{c}\text { Vitamin } \mathrm{A}, \text { vitamin } \mathrm{D} \text {, vitamin } \mathrm{B}_{2} \text { (riboflavin), } \\
\text { vitamin } \mathrm{B}_{15} \text { (pangamic acid), vitamin } \mathrm{B}_{12} \\
\text { (cyanocobalamin), calcium, phosphate }\end{array}$ \\
\hline Egg & $\begin{array}{c}\text { Vitamin } \mathrm{B}_{12}, \text { vitamin } \mathrm{B}_{2}, \text { vitamin } \mathrm{B}_{15} \text {, biotin, } \\
\text { selenium }\end{array}$ \\
\hline Soya & ${\text { Vitamin } \mathrm{B}_{1}, \text { vitamin } \mathrm{B}_{2}, \text { vitamin } \mathrm{B}_{6}, \text { folic acid, } \mathrm{Ca},}_{\mathrm{PO}_{4}, \mathrm{Mg}, \mathrm{Fe}, \mathrm{Zn}}$ \\
\hline Wheat & Vitamin $\mathrm{B}_{1}$, vitamin $\mathrm{B}_{2}$, niacin, Fe, folic acid \\
\hline Peanuts & Vitamin $\mathrm{E}$, niacin, $\mathrm{Mg}, \mathrm{Mn}, \mathrm{Cr}$ \\
\hline
\end{tabular}

- Proteins of high nutritional value are eliminated, mainly proteins of animal origin with a 10-205-fold higher availability than plant-derived proteins.

- Food allergy affects children with severe atopic dermatitis and gastrointestinal symptoms, especially since these children have higher protein and energy requirements.

- Hypersensitivity to multiple foods is present.

- Dietary instructions are not complied with (reluctance for expanding the diet), radical self-limitation of the diet. Nutritional disorders also contribute to poorer immunity in children and to impaired regeneration processes, e.g. in children with severe atopic dermatitis.

It should also be emphasised that in infants with allergy to cow milk proteins, after 16 weeks of age and before 26 weeks of age, that is during the most favourable period for inducing tolerance of potential allergens, solid foods should be introduced in the diet, which will also reduce the risk of nutritional disorders $[26,47]$.

The available treatment formulas for infants cover the requirement for protein $(1.3 \mathrm{~g} / \mathrm{kg}$ in children aged 12 months or younger; $1.0 \mathrm{~g} / \mathrm{kg}$ in older children) and calcium, provided that the child drinks the volume of the formula recommended for their age (a minimum of $500 \mathrm{ml}$ ). These formulas do not, however, cover the requirement for vitamin D or DHA. According to the 2013 paediatric guidelines, children should receive vitamin D all year long: $400 \mathrm{IU}$ at the age of 6 months old or younger, and $600 \mathrm{IU}$ at the age of 12 months old or younger [48]. Older children should receive vitamin D from September to April at a dose of 600-1000 IU [49]. Children aged 2 years or younger should additionally receive DHA at a minimum dose of $100 \mathrm{mg}$. The mother eating a milk-free diet, even if for diagnostic purposes, should always receive calcium supplementation at a dose of $1000 \mathrm{mg}[35,50], 500 \mathrm{mg}$ of DHA, and $800 \mathrm{IU}$ of vitamin D [34].

Absorption of dietary calcium is only $30 \%$ [51]. Calcium in human milk is best absorbed, followed by calcium in infant formulas, while calcium in cow milk is characterised by the poorest absorption (66\%, 40\% and 24\%, respectively). Lactose-free formulas decrease calcium absorption by about $25 \%$, which is why calcium levels in casein hydrolysates are higher than in lactose formulas. This means that calcium supplementation should not be routinely recommended to children fed these formulas [52].

In vitamin D deficiency, dietary calcium absorption decreases from $30-40 \%$ to $10-15 \%$, which is why calcium supplementation should always be combined with administration of vitamin D [53].

\section{Treatment}

\section{Dietary treatment}

The "drug" of choice in FA is a diet that eliminates the harmful product. 
The elimination diet refers to temporary or permanent removal of a harmful or suspected to be harmful food or food ingredient from the diet with simultaneous introduction of ingredients of the equivalent nutritional and energy value.

The elimination diet is the only treatment of FA which is safe and uniform for all the patients (irrespective of the pathogenetic mechanism underlying the patient's allergy and the patient's age).

The younger the child, the more it is likely that the clinical manifestations are caused by cow milk proteins.

According to the guidelines published by the European Society of Paediatric Gastroenterology, Hepatology and Nutrition (ESPGHAN), American Academy of Pediatrics (AAP) and the Group of Experts on Food Allergy of the Polish Society of Gastroenterology, Hepatology and Child Nutrition, and "The Polish position statement on FA in children and adolescents" authored by the Group, eHF and AAF formulas belong to the so-called first-choice therapeutic and nutritional products which are used in the treatment of children with allergy to cow milk proteins or allergy to multiple foods.

Formulas containing soybean proteins or rice grain proteins belong to the second-choice therapeutic and nutritional products in the causative (dietary) treatment of FA.

The high-grade cow milk protein hydrolysates available in Poland differ, among other things, in protein and carbohydrate composition, with whey hydrolysate containing lactose and casein hydrolysate being lactose-free.

Lactose, which is the major ingredient of human milk, exerts a favourable effect on the ecosystem of gut microbiota in infants and on the physiology of the colon and calcium absorption.

According to ESPGHAN, treatment of allergy to cow milk proteins not accompanied by lactose intolerance does not require its complete elimination.

In cases of IgE-mediated allergy to cow milk proteins, the decision regarding the selection of a high-grade hydrolysate may be made by determining slgE to individual fractions of cow milk.

Allergy to all the fractions of cow milk hydrolysate affects about $1 \%$ of children with hypersensitivity to cow milk proteins.

If no improvement is seen following the use of high-grade hydrolysates of whey or casein proteins, an elimination diet in which individual amino acids are the source of protein should be considered.

Absolute indications for an elimination diet include: severe allergy to cow milk proteins (e.g. non-lgE-mediated enteritis, colitis and proctitis, eosinophilic oesophagitis, enteropathy with growth impairment, and anaphylactic reactions following the ingestion of hydrolysates of casein and whey proteins).

The duration of following an elimination diet and using formulas differs from individual to individual and de- pends on factors that contribute to clinical improvement. They include: the child's age, the moment of diagnosis, clinical severity, allergy type (IgE-mediated, non-IgE-mediated), type of formula and its tolerability, involvement of factors that impair the healing process, and others.

In mild-to-moderate allergy to cow milk proteins, dietary treatment always begins from an eHF formula, and after clinical improvement is achieved, the process of acquiring tolerance of the initially harmful milk proteins should be assessed. This test should be performed after 9 to 12 months of using a milk-free diet, in collaboration with the child's physician.

In about $10 \%$ of children with allergy to cow milk proteins treated with eHF, adequate clinical improvement is not achieved, which is due to the fact that these formulas are not entirely devoid of sensitising properties. In the further course of dietary treatment, such patients are started on an elemental formula, AAF, which is completely devoid of sensitising properties.

The duration of milk-free diet in the treatment of allergy to cow milk proteins is a minimum of 6 to 12 months until the first challenge, which is usually an open challenge. During the challenge, milk is administered in gradually increasing amounts and the dose and interval between the portions should be individualised depending on the history and clinical presentation.

In order to avoid a diagnostic error in cases with lactose intolerance, the use of lactose-free milk is recommended for challenging patients with allergy to cow milk proteins.

The possibility should be kept in mind of concomitant allergy to cow milk proteins and soya, as a result of which we do not use soya-based formulas in allergy to cow milk proteins, at least in the first half year of life.

Some patients with FA develop allergy symptoms after ingestion of an allergen in a raw product but tolerate it in a processed form (cooking, baking). This phenomenon is likely to precede the development of permanent tolerance, which may become useful in immunotherapy as a factor accelerating the development of tolerance to a harmful food.

\section{Long-term pharmacological treatment}

Based on a systematic review of 3 randomised studies and 2 non-randomised studies in a total of 326 children, weak evidence supporting the use of antihistamines has been shown in children and adults with acute, non-life-threatening manifestations of FA. Prophylactic use of antihistamines may mask early symptoms of anaphylaxis and interfere with the diagnosis, delaying the administration of adrenaline. Prophylactic use of antihistamines and mast cell stabilisers is not recommended. There is also no unequivocal evidence to support longterm use of mast cell stabilisers in the treatment of FA. Systemic and topical steroids are the mainstay of antiinflammatory treatment in eosinophilic gastrointestinal 
inflammatory conditions. They may also protect from protraction of an anaphylactic reaction or a biphasic reaction, but they must not be used as the only drugs in the treatment of anaphylaxis. Despite elimination diets, steroids, antihistamines or IT, some patients are resistant to the treatment or experience adverse reactions to the treatment, hence the ongoing search for new treatment models is performed. Biological treatment offers the possibility of inhibiting specific mechanisms of FA and prevent the development of sensitisation to food allergens. IgE blockade using omalizumab offers hope for new treatment options for FA. The possibility of changing the balance of Th1/Th2 cytokines and modifying epithelial cell function and the other components of the IgE pathway is also being investigated [54]. Recent studies have also suggested new targets for FA treatment: epitheliumderived mediators (IL-33 and TSLP), IgE-binding receptors (CD23) and IgE pathway signals. Omalizumab treatment has also been shown to be an element that increases the safety and efficacy of IT.

\section{Immunotherapy}

Most children with IgE-mediated hypersensitivity to milk, eggs, wheat and soy develop tolerance before the age of 10 years, while those with non-IgE-mediated hypersensitivity do so sooner $[26,55]$. Therefore, each patient on an elimination diet should undergo a periodic assessment of tolerance of a specific food allergen. Tolerance is usually verified every 6 months in children aged 3 years or younger, followed by every 12 months. According to Sampson, tolerance should be assessed every 1 to 2 years, with the exception of situations where the level of slgE exceeds 20-50 kUA/l, when the challenge is performed every 2 to 5 years (evidence $C$ according to EBM) [5].

So far, avoidance of allergens responsible for triggering an allergic reaction has been the only effective treatment for FA in patients who fail to develop the natural tolerance of foods. Restrictive avoidance of exposure to an allergen is not always possible and can also lead to nutritional disorders and expose the patient to constant stress associated with the risk of a reaction after accidental ingestion of an allergen. New treatment perspectives for these patients are offered by immunotherapy (IT). Immunotherapy may be administered via the oral, sublingual or epicutaneous route (OIT, SLIT and EPIT, respectively). Oral IT involves oral administration of gradually increasing doses of foods to patients with allergies to these foods, which accelerates the development of clinical tolerance and enables them to eat these foods without adverse reactions. Immunotherapy may be allergenspecific or non-specific. The aim of allergen-specific IT is to desensitise or induce permanent tolerance, while nonspecific IT decreases the intensity of immune response.

Immunotherapy may lead to desensitisation and reduced risk of severe reactions upon accidental ingestion of an allergen, thus leading to improved quality of life. This treatment may be an effective method of desensitisation, not necessarily promoting the development of tolerance. Immunotherapy offers new therapeutic perspectives, especially in patients with severe and persistent FA. A principal indication for IT is symptoms of anaphylaxis in a patient with FA to a basic dietary ingredient. Although frequent, side effects of IT are usually mild. This method is also associated with a certain risk of adverse reactions, such as anaphylaxis. Currently, it can only be implemented by experienced researchers at academic centres. Immunotherapy is a promising method of treatment for FA, relieving patients from the constant fear of sudden and serious symptoms after ingestion of a "harmful" food and the never-ending struggle to avoid trace amounts of these foods in everyday life. It is unknown whether OIT may be effective in all patients, so there are patients for whom an elimination diet remains the only treatment option. A more widespread use of OIT in FA in the future requires further studies. While allergen-specific IT is a promising method of immunomodulatory treatment of $F A$, it is currently not recommended in clinical practice $[56,57]$.

The search for new effective treatments for FA remains a key issue in allergology. Attempts are being made to carry out IT with recombinant allergens and omalizumab. Treatment with omalizumab is an example of allergen-specific IT. This method of treatment has been shown to beneficially affect the increase in the tolerated threshold dose of the allergen in most patients with peanut allergy [58].

It has also been shown that during the administration of processed allergens (thermally processed) in children with FA, changes in immunological markers occur that are similar to those observed during OIT, which suggests that this method of management may affect the acceleration of tolerance development. Further studies are, however, required to confirm this hypothesis.

\section{Conflict of interest}

The authors declare no conflict of interest.

\section{References}

1. Ortolani C, Vighi G. Definition of adverse reactions to food. Allergy 1995; 50 (20 Suppl): 8-13.

2. Bruijnzeel-Koomen C1, Ortolani C, Aas K, et al. Position Paper. Adverse reactions to food. European Academy of Allergology and Clinical Immunology Subcommittee. Allergy 1995; 50: 623-35.

3. Muraro A, Werfel T, Hoffmann-Sommergruber K. EAACI food allergy and anaphylaxis guidelines: diagnosis and management of food allergy. Allergy 2014; 69: 1008-25.

4. Muraro A, Agache I, Clark A, et al. EAACI food allergy and anaphylaxis guidelines: managing patients with food allergy and community. Allergy 2014; 69: 1045-57. 
5. Sampson HA, Aceves S, Bock SA, et al. Food allergy: a practice parameter update - 2014. J Allergy Clin Immunol 2014; 134: 1016-25.

6. Boyce JA, Assa'ad A, Burks AW, et al. NIAID-Sponsored Expert Panel Guidelines for the diagnosis and management of food allergy in the United States: report of the NIAID-sponsored expert panel. J Allergy Clin Immunol 2010; 126: S1-58.

7. Johansson SG, Hourihane JO, Bousquet J, et al.; AACI (the European Academy of Allergology and Cinical Immunology) nomenclature task force. A revised nomenclature for allergy. An EAACl position statement from the EAACI nomenclature task force. Allergy 2001; 56: 813-24.

8. Boyce JA, Assa'ad A, Burks AW, et al. Guidelines for the diagnosis and management of food allergy in the United States: report of the NIAID-sponsored expert panel. J Allergy Clin Immunol 2010; 126 (6 Suppl): S1-58.

9. Sampson HA. Food allergy. Part 1. Immunopathogenesis and clinical disorders. J Allergy Clin Immunol 1999; 103: 717-28.

10. Report of the FAO Technical Consultation on Food Allergies. Rome: Food Agriculture Organisation of the United Nations 1995.

11. Wróblewska B. Wielka ósemka alergenów pokarmowych. Terapia 2002; 4: 15-22.

12. Kaczmarski M, Wasilewska J, Jarocka-Cyrta E, et al. Polskie stanowisko w sprawie alergii pokarmowej u dzieci i młodzieży. Post Dermatol Alergol 2011; 28 (Supl. 2): s75-115.

13. Wong GWK. Epidemiology; international point of view, from childhood to adults, food allergens. In: Food Allergy: Molecular Basis and Clinical Practice. Chem Immunol Allergy. Ebisawa M (Sagamihara), Ballmer-Weber BK (Zurich), Vieths S (Langen), Wood RA (Baltimore, Md.) (eds). Karger, Basel 2015; 30-7.

14. Prescott SL, Allen KJ. Food allergy: riding the second wave of the allergy epidemic. Pediatr Allergy Immunol 2011; 22: 155-60.

15. Kaczmarski M, Bartuzi Z. Wybrane aspekty epidemiologiczne alergii pokarmowej wieku dziecięco-młodzieżowego i dorosłego. Alergol Pol 2016; 3: 46-55.

16. Roehr CC, Edenharter G, Reimann S, et al. Food allergy and non-allergic hypersensitivity in children and adolescents. Clin Exp Allergy 2004; 34: 1534-54.

17. Prescott SL, Pawankar R, Allen KJ, et al. A global survey of changing patterns of food allergy burden in children. WAO J 2013; 6: 1-12.

18. Samoliński B, Raciborski F, Lipiec A, et al. Epidemiologia chorób alergicznych w Polsce ECAP. Alergol Pol 2014; 1: 10-8.

19. Schoemaker AA, Sprikkelman AB, Grimshaw KE, et al. Incidence and natural history of challenge-proven cow's milk allergy in European children - EuroPrevall birth cohort. Allergy 2015; 70: 963-72.

20. Majkowska-Wojciechowska B, Wardzyńska A, Łuczyńska M, et al. Nadwrażliwość na pokarmy w populacji dzieci szkolnych w Łodzi - wyniki badań ankietowych w projekcie EuroPrevall. Alergia Astma Immunologia 2009; 14: 35-44.

21. Canonica GW, Ansotegui IJ, Pawankar R, et al. A WAO - ARIA - GA2LEN consensus document on molecular-based allergy diagnostics. World Allergy Organ J 2013; 6: 17.

22. Schoos AMM, Chawes BLK, Følsgaard NV, et al. Disagreement between skin prick test and specific IgE in young children. Allergy 2015; 70: 41-8.

23. Sampson HA. Utility of food-specific IgE concentrations in predicting symptomatic food allergy. J Allergy Clin Immunol 2001; 107: 891-6.
24. Stiefel G, Roberts G. How to use serum-specific IgE measurements in diagnosis and monitoring food allergy. Arch Dis Child Educ Pract Ed 2012; 97: 29-36.

25. Clark AT, Skypala L, Leech SC, et al. British Society for Allergy and Clinical Immunology guidelines for the management of egg allergy. Clin Exp Allergy 2010; 40: 1116-29.

26. Fiocchi A, Brozek J, Schunemann H, et al. World Allergy Organization (WAO) Diagnosis and Rationale for Action against Cow's Milk Allergy (DRACMA) Guidelines. Pediatr Allergy Immunol 2010; 21 (Suppl. 21): 1-125.

27. Nowak-Wegrzyn A, Bloom KA, Sicherer SH, et al. Tolerance to extensively heated milk in children with cow's milk allergy. J Allergy Clin Immunol 2008; 122: 342-7.

28. Hoffmann HJ, Santos AF, Mayorga C, et al. The clinical utility of basophil activation testing in diagnosis and monitoring of allergic disease. Allergy 2015; 70: 1393-405.

29. Ito K, Futamura M, Movérare R, et al. The usefulness of casein-specific IgE and IgG4 antibodies in cow's milk allergic children. Clin Mol Allergy 2012, 10: 1-7.

30. Hong X, Caruso D, Kumar R, et al. IgE but not IgG4 antibodies to Ara h2 distinguish peanut allergy from asymptomatic peanut sensitization. Allergy 2012; 67: 1538-46.

31. Gocki J, Bartuzi Z. Role of immunoglobulin $\mathrm{G}$ antibodies in diagnosis of food allergy. Post Dematol Alergol 2016, 33: 253-7.

32. Sicherer SH, Sampson HA. Food allergy. J Allergy Clin Immunol 2010; 125 (Suppl 2): S116-25.

33. Niggemann B, Beyer K. Diagnosis of food allergy in children: toward a standardization of food challenge. J Pediatr Gastroenterol Nutr 2007; 45: 399-404.

34. Burks AW, Tang M, Scott $H$, et al. ICON: food allergy. J Allergy Clin Immunol 2012; 129: 906-20.

35. Vandenplas Y, Brueton M, Dupont C, et al. Guidelines for the diagnosis and management of cow's milk protein allergy in infants. Arch Dis Child 2007; 92: 902-8.

36. Luyt D, Ball H, Makwana N, et al. BSACI guideline for the diagnosis and management of cow's milk allergy. Clin Exp Allergy 2014; 44: 642-72.

37. Host A, Husby S, Hansen LG, et al. Bovine beta-lactoglobulin in human milk from atopic and nonatopic mothers. Relationship to maternal intake of homogenized and unhomogenized milk. Clin Exp Allergy 1990; 20: 383-7.

38. Niggemann B, Rollinck-Werninghaus C, Mehl A, et al. Controlled oral food challenges in children-when indicated, when superfluous? Allergy 2005; 60: 865-70.

39. Koletzko S, Niggemann B, Arato A, et al. Diagnostic approach and managment of cow's milk protein allergy in infants and children. ESPGHAN GI Committee practical Guidelines. J Pediatr Gastroenterol Nutr 2012; 55: 221-9.

40. Jarocka-Cyrta E, Nowak-Węgrzyn A, Ruszczyński M, et al. Doustne próby prowokacji w diagnostyce alergii na białka mleka krowiego. Stanowisko Grupy Roboczej Sekcji Alergii Pokarmowej PTGHiżDz. Standardy Medyczne. Pediatria 2015; 12: 501-16.

41. Chapman JA, Bernstein IL, Lee RE, et al. Food allergy: a practice parameter. Ann Allergy Asthma Immunol 2006; 96 (3 Suppl. 2): 1-68.

42. Mehta H, Ramesh M, Feuille E, et al. Growth comparison in children with and without food allergies in 2 different demographic populations. J Pediatr 2014; 165: 842-8.

43. Giovannini M, D’Auria E, Caffarelli C, et al. Nutritional management and follow up of infants and children with food allergy. Ital J Pediatr 2014; 40: 1. 
44. Vieira MC, Morais MB, Spolidoro JVN, et al. A survey on clinical presentation and nutritional status of infants with suspected cow' milk allergy. BMC Pediatr 2010; 1025: 1-7.

45. Prescott SL, Smith P, Tang M, et al. The importance of early complementary feeding in the development of oral tolerance: concerns and controversies. Pediatr Allergy Immunol 2008; 19: 375-380.

46. Sinai T, Amitzur-Levi R, Nachshon L, et al. A positive association has been reported between milk consumption and growth parameters. Inadequate nutrient intake and short stature in subjects with diagnosed milk protein allergy. ESPEGHAN 2014 AHP-0004.

47. Allen CW, Campbell DE, Kemp AS. Food allergy: is strict avoidance the only answer? Pediatr Allergy Immunol 2008; 20: 415-22.

48. Mojska H. Opinia naukowa Europejskiego Urzędu ds. Bezpieczeństwa Żywności (EFSA), dotycząca zalecanego dziennego spożycia tłuszczu i kwasów tłuszczowych jako podstawa do tworzenia rekomendacji krajowych. Standardy Medyczne/Pediatria 2012; 9: 195-200.

49. Vesa TH, Marteau P, Korpela R. Lactose intolerance. J Am Coll Nutr 2000; 19 (2 Suppl): 165S-75S.

50. Cheng S, Lyytikainen A, Kröger H, et al. Effects of calcium, dairy product, and vitamin $\mathrm{D}$ supplementation on bone mass accrual and body composition in 10-12-y-old girls: a 2-y randomized trial. Am J Clin Nutr 2005; 82: 1115-26.

51. Straub DA. Calcium supplementation in clinical practice: a review of forms, doses, and indications. Nutr Clin Pract 2007; 22: 286-96.

52. Abrams SA, Griffin IJ, Davila PM. Calcium and zinc absorption from lactose-containing and lactose free infant formulas. Am J Clin Nutr 2002; 76: 442-6.

53. Płudowski P, Karczmarewicz E, Chlebna-Sokół D, et al. Witamina D: Rekomendacje dawkowania w populacji osób zdrowych oraz w grupach ryzyka deficytów - wytyczne dla Europy Środkowej 2013. Standardy Medyczne/Pediatria 2013; 10: 573-8.

54. de Silva D, Geromi M, Panesar SS, et al. A on behalf of the EAACI Food Allergy and Anaphylaxis Guidelines Group. Acute and long-term management of food allergy: systematic review. Allergy 2014; 69: 159-67.

55. Rolinck-Werninghaus C, Staden U, Mehl A, et al. Specific oral tolerance induction with food in children: transient or persistent effect on food allergy? Allergy 2005; 60: 1320-2.

56. Eigenmann PA, Beyer K, Wesley Burks AW, et al. New visions for food allergy: an iPAC summary and future trends. Pediatr Allergy Immunol 2008; 19 Suppl.: 26-39.

57. Staden U, Rolinck-Werninghaus C, Brewe F, et al. Specific oral tolerance induction in food allergy in children: efficacy and clinical pattern of reaction. Allergy 2007; 62: 1261-9.

58. Leung DYM, Sampson HA, Yunginger JW, et al. Effect of antiIgE therapy in patients with peanut allergy. N Engl J Med 2003; 348: 986-93. 